\title{
Tree growth, mortality and recruitment in four inland tropical dry evergreen forest sites of Peninsular India
}

\author{
ELUMALAI PANDIAN", NARAYANASWAMY PARTHASARATHY \\ Department of Ecology and Environmental Sciences, Pondicherry University, Puducherry-605014, India. "email: pandianmaha11@gmail.com
}

Manuscript received: 24 May 2017. Revision accepted: 23 October 2017.

\begin{abstract}
Pandian E, Parthasarathy N. 2017. Tree growth, mortality and recruitment in four inland tropical dry evergreen forest sites of Peninsular India. Biodiversitas 18: 1646-1656. Tree diversity was re-inventoried after a decade (2003-2013) for assessing growth, mortality and recruitment rates in four inland tropical dry evergreen forest sites on the Coromandel Cost of India. Four 1-ha square plots $(100 \mathrm{~m} \times 100 \mathrm{~m})$ were established in 2003 in four tropical dry evergreen forest sites, i.e. Araiyapatti (AP), Karisakkadu (KR), Maramadakki (MM) and Shanmuganathapuram (SP). These four plots were re-inventoried in 2013 to determine decadal changes in tree diversity. All trees $\geq 10 \mathrm{~cm}$ girth at breast height (gbh) were measured at $1.3 \mathrm{~m}$ from the ground level. The initial inventories in 2003 recorded 57 tree species, whereas, in 2013, 56 species were recorded from 46 genera and 26 families. Tree basal area declined by $6.2 \%$ and $3.4 \%$ in sites KR and SP respectively, whereas in the other two sites it increased; AP (1.6\%) and MM (16.8\%). The mean growth rate of trees $(\geq 10 \mathrm{~cm} \mathrm{gbh})$ in four tropical dry evergreen forest sites ranged from 0.68 to $1.52 \mathrm{~cm} \mathrm{yr}^{-1}$. High recruitment rate was recorded in less disturbed sites $\mathrm{KR}\left(21.8 \% \mathrm{yr}^{-1}\right)$ and $\mathrm{MM}\left(11.5 \% \mathrm{yr}^{-1}\right)$, while the moderately disturbed sites showed $9.1 \% \mathrm{yr}^{-1}$ in site $\mathrm{AP}$ and $5.1 \% \mathrm{yr}^{-1}$ in site SP. Mortality rates were 23.5 and $45.7 \% \mathrm{yr}^{-1}$ in highly disturbed sites AP and SP respectively.
\end{abstract}

Keywords: Forest dynamics, mortality, recruitment, tree growth, tropical dry evergreen forest

\section{INTRODUCTION}

Long-term studies are important for assessing the forest dynamics (Pandian and Parthasarathy 2016). The understanding of the tree growth is important in many ecological and management applications, not only is it a basic demographic process that profoundly influences tree population dynamics (Harcombe 1987; Metcalf et al. 2009), but it is also one of the primary means of evaluating forest management goals (Chojnacky 2001). Several ecological studies examined population changes by counting and later recounting a defined sample and assessing survivors, losses, and gains (Sheil and May 1996). Such information is commonly summarized as rates of mortality, recruitment, or turnover in tropical forest studies (e.g., Phillips et al. 1994; Sheil et al. 1995).

Repeated measurements of permanent forest plots across the tropics have shown increased tree growth over the past decades in many cases (Lewis et al. 2004; 2009), but decelerating or stable growth rates in others (Feeley et al. 2007; Clark et al. 2010). Permanent tree plots have been established in Mudumalai Game Reserve (Sukumar et al. 1992, 1998), Uppangala reserve forest (Pascal and Pelissier 1996) and in Varagalaiar, Anamalasis (Ayyappan and Parthasarathy 1999). Population density and competition is a fundamentally limiting factor (Lines et al. 2010; Kunstler et al. 2011) in closed-canopy conditions In addition, the supply of energy, water, and nutrients (typically measured by proxies such as insolation, water deficit, and soil type) can strongly limit tree growth and can mask density dependence (He and Duncan 2000). There is strong evidence that the growth rates of tropical forest trees have increased over the last few decades (Laurance et al. 2004; Phillips et al. 2008), probably as a result of increased atmospheric $\mathrm{CO}_{2}$ concentration (Lloyd and Farquhar 2008). Our study was conducted in tropical dry evergreen forest sites which are disappearing at an alarming rate due to anthropogenic activities and are replaced by forests composed of different species or their land use pattern is changed (Parthasarathy 1999; Chittibabu and Parthasarathy 2000). Our study was undertaken with an aim to investigate decadal changes (2003-2013) in tree species richness, abundance, growth, mortality and recruitment rate in four inland Indian tropical dry evergreen forests on the Coromandel Coast of India.

\section{MATERIALS AND METHODS}

\section{Study area}

The study was conducted in four inland tropical dry evergreen forest sites (Araiyapatti/AP, Karisakkadu/KR, Maramadakki/MM and Shanmuganathapuram/SP) which are located around $40 \mathrm{~km}$ west of the eastern coast in Pudukottai District $\left(9^{\circ} 50^{\prime \prime}\right.$ and $10^{\circ} 40^{\prime \prime}, 78^{\circ} 25^{\prime \prime}$ and $\left.79^{\circ} 15^{\prime \prime}\right)$ of Tamil Nadu, southern India (Figure 1).

All the four study sites are sacred groves or temple forests and are protected based on the religious belief systems of local people. Sites MM and SP were located near to human settlement, while in sites AP and KR were nearly $300 \mathrm{~m}$ from habitation. Agricultural fields of paddy, maize, millet, Casuarina, sugarcane and vegetable plantations surround all the study sites. Distance between the four studied sites ranged from 4 to $25 \mathrm{~km}$. The four 
study sites experience various levels of anthropogenic disturbance (Pandian and Parthasarathy 2016). Anthropogenic activities are high in highly disturbed sites AP and SP, where selectively logged (tree felling for poles, timber, and fuelwood extraction) by local people, whereas $\mathrm{MM}$ is a least disturbed site while $\mathrm{KR}$ is a moderately disturbed site (Table S1). The climate data available for 1992-2012 from the nearest station (located $15 \mathrm{~km}$ away from our study sites) reveal mean annual rainfall of 1033 $\mathrm{mm}$ per year received largely during the northeast monsoon (October-December) with a mean annual temperature of $29.5^{\circ} \mathrm{C}$. The mean annual maximum and minimum temperature ranges from $33.4^{\circ} \mathrm{C}$ to $25.4^{\circ} \mathrm{C}$ for the same period (Pandian and Parthasarathy 2016). The vegetation of all our study sites is described as tropical dry evergreen forests (Type 7/CI of Champion and Seth (1968); Mani and Parthasarathy (2005). Soils are basically lateritic and sandy to sandy loam in texture in all the sites.

\section{Methods}

Four 1-hectare permanent plots $(100 \mathrm{~m}$ x $100 \mathrm{~m})$ were established a decade ago (2003) in four tropical dry evergreen forest sites, AP, MM, KR and SP. All trees $\geq 10$ $\mathrm{cm}$ girth at breast height ( $\mathrm{gbh}$ ) was measured at $1.3 \mathrm{~m}$ from the ground level (Mani and Parthasarathy 2005). These four plots were re-inventoried in 2013 to determine the tree diversity changes over a decade. We follow the same methodology for each 1 ha plot and each was subdivided into one-hundred $10 \mathrm{~m}$ x $10 \mathrm{~m}$ quadrats. For multistemmed trees, bole girths were measured separately. The recensus (2013) results were compared with initial inventories (2003) to assesses the changes in tree growth, mortality, and recruitment rate over a decade (2003-2013) at species and stand levels.

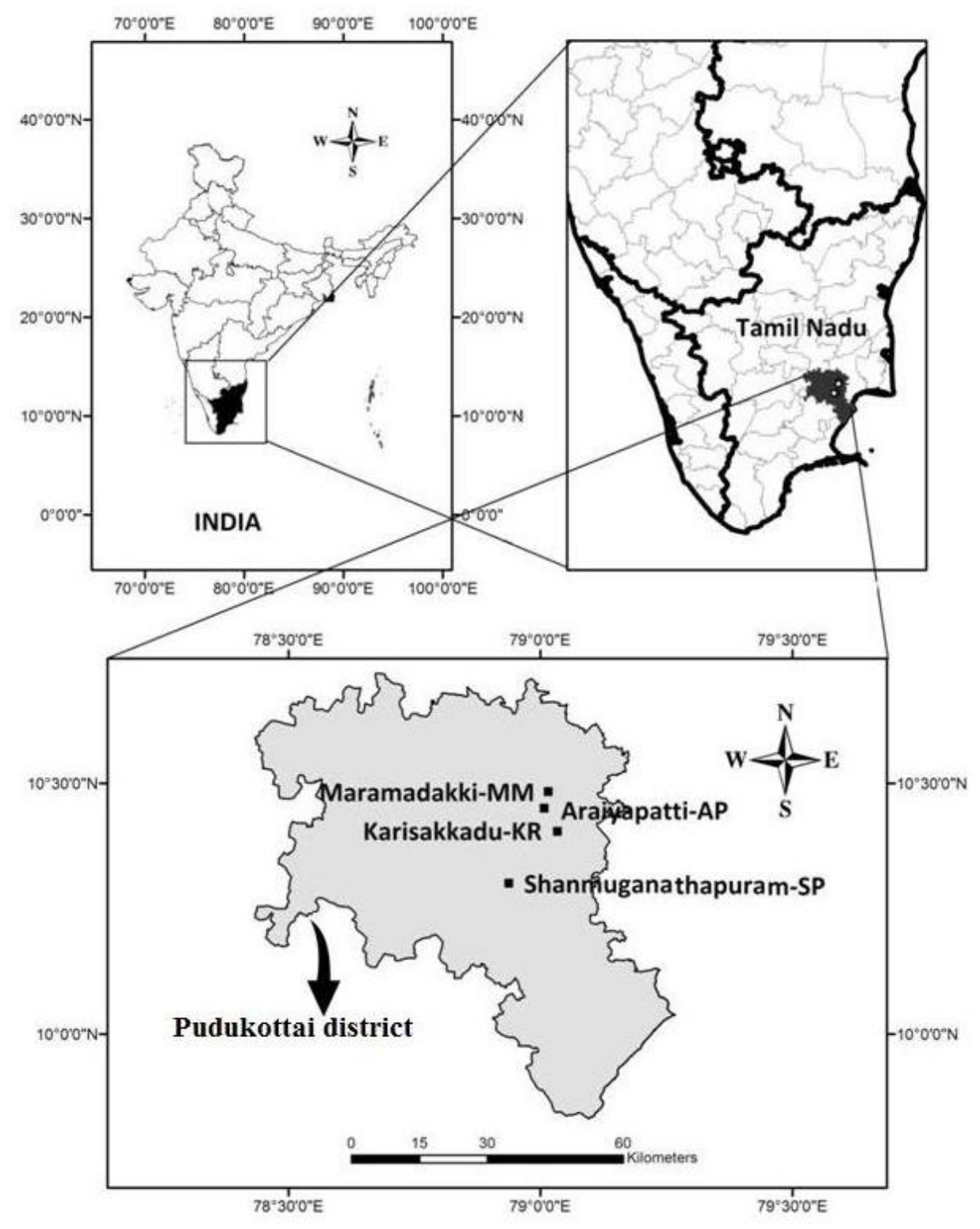

Figure 1. Map showing the location of four tropical dry evergreen forest sites on the Coromandel Coast of India (Maramadakki (MM), Karisakkadu (KR), Araiyapatti (AP) and Shanmuganathapuram (SP) in Pudukottai District of Tamil Nadu state, India) 
Table 1. Decadal changes $(2003$ \& 2013) in tree diversity in four tropical dry evergreen forest sites - Araiyapatti (AP), Karisakkadu (KR), Maramadakki (MM) and Shanmuganathapuram (SP) on the Coromandel Coast of peninsular India

\begin{tabular}{|c|c|c|c|c|c|c|c|c|c|c|c|c|}
\hline \multirow{2}{*}{ Variable } & \multicolumn{3}{|c|}{ AP } & \multicolumn{3}{|c|}{ KR } & \multicolumn{3}{|c|}{ MM } & \multicolumn{3}{|c|}{ SP } \\
\hline & 2003 & 2013 & Net change & 2003 & 2013 & Net change & 2003 & 2013 & Net change & 2003 & 2013 & Net change \\
\hline Species richness & 35 & 37 & 2 & 30 & 31 & 1 & 28 & 27 & -1 & 26 & 29 & 3 \\
\hline Stand density (stems ha- ${ }^{1}$ ) & 807 & 705 & -102 & 596 & 678 & 82 & 724 & 750 & 26 & 1663 & 1182 & -481 \\
\hline Stand basal area $\left(\mathrm{m}^{2} \mathrm{ha}^{-1}\right)$ & 19.1 & 19.43 & 0.42 & 21.6 & 20.26 & -1.34 & 15.5 & 18.63 & 3.13 & 22.1 & 20.38 & -1.72 \\
\hline
\end{tabular}

Each tree tag number was verified and its species reconfirmed by collecting a voucher specimen. In the case of trees that had lost their tags, the species and its girth was compared to previous data and also to its nearest neighbors to ensure measurement of all trees. Original inventory trees that were dead or had disappeared were classified as dead. Recruits were appended with aluminum tags (number distinguishable from those of original inventory) and voucher specimens were collected. All trees were identified from their vegetative and reproductive features using the regional floras (Gamble and Fischer 1915-1935; Henry et al. 1987, 1989; Matthew 1991; Nair and Henry 1983) and the field key of Pascal and Ramesh (1987). The differences in diameter distribution of trees between the two inventories (2003-2013) were tested using KolmogorovSmirnov two-sample test (Zarr 2006), and we used paired ttests to check for the significant differences in tree variables across four forest sites using SPSS software. A six-letter code was assigned to all species (for floristic structure) with the first three letters denoting the generic name and the next three letters, the specific epithet. The mean growth rates were calculated for all species. Mean girth was taken in each species and its growth was calculated from 2003. Annual rates of mortality and recruitment were calculated from the equation of Newbery et al. (1999).

$$
\begin{aligned}
& \text { Mortality rate }(\mathrm{m})=1-\left[1-\left(\mathrm{n}_{\mathrm{d}} / \mathrm{n}_{03}\right)\right]^{1 / \mathrm{t}} \\
& \text { Recruitment rate }(\mathrm{r})=\left[1+\left(\mathrm{n}_{\mathrm{r}} / \mathrm{n}_{03}\right)\right]^{1 / \mathrm{t}}-1
\end{aligned}
$$

Where, $\mathrm{t}=$ relevant time interval, $\mathrm{n}_{\mathrm{d}}=$ number of death, $\mathrm{n}_{\mathrm{r}}=$ number of recruits and $\mathrm{n}_{03}=$ population size in 2003 .

\section{RESULTS AND DISCUSSION}

The re-inventory of trees in the four sites showed substantial changes in species richness, density, basal area and tree growth over a decade. There was significant change in species richness $(\mathrm{df}=99, \mathrm{p}<0.05$; except in $\mathrm{SP})$, density $(\mathrm{df}=99, \mathrm{p}<0.05)$ and basal area $(\mathrm{df}=99, \mathrm{p}<0.05$; except in KR) in the ten-year interval (2003-2013). The initial inventory was carried out in 2003 and yielded 57 tree species, whereas in 2013 a total of 56 tree species were recorded, with an overall loss of three species and two species as a new addition in the ten-year interval. Among the four studied sites, the species richness in 2013 ranged from 27 species in site MM to a high of 37 species in AP, through intermediate values of 30 and 29 species KR and $\mathrm{SP}$ respectively (Table 1). This could be attributed either to natural cause of tree death or due to human interference, during the ten-year gap. Sheil et al. (2000) also reported increased species richness over a time period (1944-1992) in Budongo rain forest, Uganda. In contrast, Fashing et al. (2004) reported that tree species richness declined by $21 \%$ over an 18-year gap in Kakamega forest, Kenya.

The stand density decreased in ten-year interval by 480 and 102 stems in SP and AP respectively, but increased moderately by 82 stems in KR and 26 stems in MM. This could be attributed to the removal of stems by local residents, whereas in moderately disturbed sites density increased by 82 stems in KR and 26 stems in MM. Over decades, stem density showed sharp reduction in coastal tropical dry evergreen forest sites (Baithalu et al. 2012, 2013; Mani and Parthasarathy 2009. Felfili (1995) also reported $2 \%$ of density decreased over a six-year period in the gallery forest of Central Brazil. In another Brazilian site, Felfili et al. (2000) reported that the stem density declined by $4.5 \%$ over a nine-year period. The tree basal area per hectare declined in site KR from $21.6 \mathrm{~m}^{2}$ to 20.26 $\mathrm{m}^{2}$ and in site SP from $22.1 \mathrm{~m}^{2}$ to $20.38 \mathrm{~m}^{2}$, but increased from $19.1 \mathrm{~m}^{2}$ to $19.43 \mathrm{~m}^{2}$ in AP and from $15.5 \mathrm{~m}^{2}$ to 18.63 $\mathrm{m}^{2}$ in MM (Table 1). Tree basal area increased in all the girth classes (except 121-150 cm) in site MM, while in site $\mathrm{KR}$, basal area increased only in highest girth class (151180 and $>210 \mathrm{~cm}$ ) but in other girth classes it decreased. Whereas in site AP, it decreased in lower and higher girth classes but moderately increased in middle girth class. In site SP, basal area decreased in lower and middle girth classes, but its increased in higher girth classes (Figure 2). This could be due to anthropogenic pressure, (by the way of cutting tree). Bhat et al. (2000) also found decreased basal area with increasing human disturbance in tropical forests of Western Ghats, India. Laurance et al. (2009) reported tree basal area increased by $4 \%$ in central Amazonian forests and Krisnawati et al. (2011) also reported an increase in basal area over a 4.3-year time period in Samboja research forest, east Kalimantan, while Hitimana et al. (2004) reported that the basal area in larger diameter classes has become reduced in western Kenya.

\section{Tree girth increment by species}

Overall mean girth increment rate by species ranged from $0.05 \pm 0.18$ to $3.53 \pm 1.17 \mathrm{~cm} \mathrm{yr}^{-1}$ across the four study sites. Among the 56 tree species greatest girth increment was shown by Ficus benghalensis $\left(3.53 \pm 1.17 \mathrm{~cm} \mathrm{yr}^{-1}\right)$, its density increased just by one individual (1stem), followed 
by Syzygium cumini $\left(2.03 \pm 1.73 \mathrm{~cm} \mathrm{yr}^{-1}\right)$ and its density (3 stem) declined and Ficus religiosa $\left(1.70 \pm 0.28 \mathrm{~cm} \mathrm{yr}^{-1}\right)$ no change occurred in density and above mensioned tree species basal area was increased by $0.173 \mathrm{~m}^{2}, 0.776 \mathrm{~m}^{2}$ and $0.059 \mathrm{~m}^{2}$ respectively. Whereas Benkara malabarica $\left(0.06 \pm 0.01 \mathrm{~cm} \mathrm{yr}^{-1}\right)$, Clausena dentata $\left(0.06 \pm 0.02 \mathrm{~cm} \mathrm{yr}^{-1}\right)$ and Diospyros ferrea $\left(0.05 \pm 0.18 \mathrm{~cm} \mathrm{yr}^{-1}\right)$ showed lowest girth increment, but its density increased (by 7, 5 and 2 stems respectively) and basal area by $0.012 \mathrm{~m}^{2}, 0.009 \mathrm{~m}^{2}$ and $0.006 \mathrm{~m}^{2}$ respectively over a decade (Table 2 ). These values, when compared to other forests, are greater than those of $0.25 \mathrm{~cm} \mathrm{yr}^{-1}$ in central Brazil (Felfili 1995), 0.11 to $0.65 \mathrm{~cm} \mathrm{yr}^{-1}$ in Puerto Rico (Schmidt and Weaver 1981), 0.26 to $0.78 \mathrm{~cm} \mathrm{yr}^{-1}$ in northwestern Costa Rica (Chapman and Chapman 1990), $0.44 \mathrm{~cm} \mathrm{yr}^{-1}$ in Uganda (Taylor et al. 1996); but it is well within the range of 0.08 to $1.15 \mathrm{~cm} \mathrm{yr}^{-1}$ reported in Panama (Lang and Knight 1983) and 0.04 to $1.30 \mathrm{~cm} \mathrm{yr}^{-1}$ in Costa Rica (Lieberman et al. 1985). Increments of tree diameter may vary widely between measurement periods over the short-term, thus biasing estimates of plant species-specific growth rates (Clark and Clark 1994). Our results are closer to those reported by Dong et al. (2012) that a five-year mean growth rate at Huai Kha Khaeng (HKK) was $0.23 \mathrm{~cm} \mathrm{yr}^{-1}$ during the first census (1994-1999) interval, but declined to $0.21 \mathrm{~cm} \mathrm{yr}^{-1}$ during the second census (1999-2004) interval. In contrast, at Lambir, the five-year stand-level mean tree growth rate has increased from $0.065 \mathrm{~cm}$ to $0.067 \mathrm{~cm} \mathrm{yr}^{-1}$ between the two census intervals (1992-1997 and 1997-2002). In terms of direction, this corresponds to a decrease by $0.02 \mathrm{~cm} \mathrm{yr}$ ${ }^{1}$ at HKK and increase by $0.002 \mathrm{~cm} \mathrm{yr}^{-1}$ for Lambir.

\section{Mean tree girth increment by size class}

In the four sites, the mean girth increment varied considerably across the girth classes. Maximum girth increment was found in the larger size classes at site MM $\left(4.3 \mathrm{~cm} \mathrm{yr}^{-1}\right)$, followed by AP $\left(3.1 \mathrm{~cm} \mathrm{yr}^{-1}\right)$, SP $(2.9 \mathrm{~cm} \mathrm{yr}$ $\left.{ }^{1}\right)$ and $\mathrm{KR}\left(0.92 \mathrm{~cm} \mathrm{yr}^{-1}\right)$. Whereas the lowest and middle girth class showed low girth increment in all the study sites (Figure 3). Mean girth increment rate was calculated by girth class for all the species (Table S2).

\section{Girth increment in dominant species by girth class}

The mean girth increment of four abundant species varied considerably (Figure 4); particularly Albizia amara showed greater girth increment in higher girth class in sites MM (3.8 $\left.\mathrm{cm} \mathrm{yr}^{-1}\right)$ and AP $\left(2.9 \mathrm{~cm} \mathrm{yr}^{-1}\right)$, but in site SP it increased in all the girth classes; while in site KR showed a moderate increase, except in higher girth class. Girth increment in Memecylon umbellatum was low in lowest girth class in all the sites, whereas it was greater in middle girth classes in all sites (except in KR). In Drypetes sepiaria, the girth increment was greater in higher girth classes in sites MM $\left(1.55 \mathrm{~cm} \mathrm{yr}^{-1}\right), \mathrm{KR}\left(1.2 \mathrm{~cm} \mathrm{yr}^{-1}\right)$ and SP $\left(1.6 \mathrm{~cm} \mathrm{yr}^{-1}\right)$, but in site AP $\left(1.7 \mathrm{~cm} \mathrm{yr}^{-1}\right)$ it was greater in lower girth class. In Glycosmis mauritiana girth increment is high only in lower girth class. This result is accordance with Sundaram and Parthasarathy (2002) at Kolli hills wherein the six species showed a $>3.5 \mathrm{~cm} \mathrm{yr}^{-1}$ difference between their maximum and minimum growth rates and such fast-growing species are ideal for afforesting degraded sites. Elouard et al. (1997) reported a similar inter and intra-specific variability in individual diameter increment of trees $\geq 30 \mathrm{~cm}$ gbh in the forest of Kadamakal, Western Ghats, India. The repeated measurements of permanent forest plots across the tropics have shown increase the tree growth over the past decades in many cases (Lewis et al. 2009, 2004), but decelerating or stable growth rates in others (Fleeley et al. 2007; Clark et al. 2010). One of the major factors suggested causing an increased tree growth is the rise in atmospheric $\mathrm{CO}_{2}$ concentration, as it can increase plant photosynthetic rates and enhance water-use efficiency (Holtum et al. 2010; Keenan et al. 2013). However, in a study at La Selva in Costa Rica, researchers found that growth rates declined in six canopy species during 1984-2000 (Clark et al. 2003); and the same trend of decelerating growth was also found from large forest dynamics plots in Panama and Malaysia (Feeley et al. 2007).

\section{Changes in mortality, recruitment, and turnover over a decade}

The mean growth rate of trees $(\geq 10 \mathrm{~cm} \mathrm{gbh})$ in four tropical dry evergreen forest sites ranged from 0.68 to 1.52 $\mathrm{cm} \mathrm{yr}^{-1}$ (Table 3). Taylor et al. (1996) reported a mean annual increment of $0.44 \mathrm{~cm} \mathrm{yr}^{-1}$ for trees $\geq 9.5 \mathrm{~cm} \mathrm{dbh}$ in Mpanga, Uganda. Sundaram and Parthasarathy (2002) reported a mean annual girth increment for trees $\geq 30 \mathrm{~cm}$ gbh that ranged from $1.42 \mathrm{~cm} \mathrm{yr}^{-1}$ in site Perumakkai Shola (PS) to $2.60 \mathrm{~cm} \mathrm{yr}^{-1}$ in site Mottukadu Shola (MS) in Kolli hills, Eastern Ghats. These values are greater than that of $0.27 \mathrm{~cm} \mathrm{yr}^{-1}$ exhibited by trees $\geq 30 \mathrm{~cm} \mathrm{dbh}$ in Mount Bellenden-Ker, Queensland (Herwitz and Young 1994). Amazon forests had been observed to be experiencing accelerated dynamics over the past several decades, including significantly increased rates of tree growth, mortality, recruitment and aboveground biomass (Lewis et al. 2004b; Phillips et al. 2004; Baker et al. 2004). Stimulation of individual diameter increment due to logging in forest sites has been reported for trees $\geq 30 \mathrm{~cm}$ gbh in a dense moist evergreen forest in Kadamakal, Indian Western Ghats (Elouard et al. 1997).

The maximum diameter increment rate was recorded in site AP (1.19 $\left.\mathrm{cm} \mathrm{yr}^{-1}\right)$ followed by KR $\left(1.15 \mathrm{~cm} \mathrm{yr}^{-1}\right), \mathrm{MM}$ $\left(1.52 \mathrm{~cm} \mathrm{yr}^{-1}\right)$ and SP $\left(0.68 \mathrm{~cm} \mathrm{yr}^{-1}\right)$. The mortality rate was high in the highly disturbed sites SP $\left(45.7 \% \mathrm{yr}^{-1}\right)$ and AP $\left(23.5 \% \mathrm{yr}^{-1}\right)$, while in the least disturbed sites mortality rate was less $\left(9.7 \% \mathrm{yr}^{-1}\right.$ in site $\mathrm{KR}$ and $8 \% \mathrm{yr}^{-1}$ in site $\left.\mathrm{MM}\right)$.

Table 3. Mean tree growth rate, mortality, recruitment and turnover rate in four tropical dry evergreen forest sites - (AP, KR, $\mathrm{MM}$ and SP) on the Coromandel Coast of peninsular India

\begin{tabular}{llllll}
\hline Variable & Site & & & & \multirow{2}{*}{ Mean $( \pm$ SD $)$} \\
\cline { 2 - 5 } & AP & KR & MM & SP & \\
\hline $\begin{array}{l}\text { Mean girth increment } \\
\left(\mathrm{cm} \mathrm{yr}^{-1}\right)\end{array}$ & 1.196 & 1.15 & 1.52 & 0.68 & $1.14 \pm 0.35$ \\
Mortality $\left(\% \mathrm{yr}^{-1}\right)$ & 23.5 & 9.7 & 8 & 45.7 & $21.7 \pm 17.43$ \\
Recruitment $\left(\% \mathrm{yr}^{-1}\right)$ & 9.1 & 21.8 & 11.5 & 5.1 & $11.8 \pm 7.12$ \\
Turnover rate $(\%)$ & 16.3 & 15.7 & 9.7 & 25.4 & $16.7 \pm 6.48$ \\
\hline
\end{tabular}


Table 2. Summary of density (stems ha $\left.{ }^{-1}\right)$ and basal area $\left(\mathrm{m}^{2} \mathrm{ha}^{-1}\right)$ of all tree species $(\geq 10 \mathrm{gbh})$ during 2003 and 2013 inventories and number of stems surviving, dead, recruited and mean girth increment $\left(\mathrm{cm} \mathrm{yr}^{-1}\right)$ in four inland tropical dry evergreen forest sites AP, KR $\mathrm{MM}$ and SP. Data were pooled.

\begin{tabular}{|c|c|c|c|c|c|c|c|c|c|}
\hline \multirow[b]{2}{*}{ Species } & \multirow[b]{2}{*}{ Family } & \multicolumn{2}{|c|}{ Density } & \multicolumn{2}{|c|}{ Basal area } & \multirow[b]{2}{*}{$\begin{array}{c}\text { Survi- } \\
\text { ving }\end{array}$} & \multirow[b]{2}{*}{ Died } & \multirow{2}{*}{$\begin{array}{l}\text { Re- } \\
\text { cruit- } \\
\text { ment }\end{array}$} & \multirow{2}{*}{$\begin{array}{l}\text { Mean girth } \\
\text { increment } \\
\text { rate }\left(\mathrm{cm} \mathrm{yr}^{-1}\right. \\
\text { and } \pm \mathrm{SD})\end{array}$} \\
\hline & & 2003 & 2013 & 2003 & 2013 & & & & \\
\hline Acacia leucophloea (Roxb.) Willd. & Mimosaceae & 3 & 4 & 0.08641 & 0.08837 & 3 & - & 1 & $0.74 \pm 0.32$ \\
\hline Albizia amara (Roxb.) Boivin & Mimosaceae & 164 & 144 & 8.55742 & 8.67098 & 164 & 20 & - & $1.50 \pm 0.37$ \\
\hline Albizia lebbeck (L.) Benth. & Mimosaceae & 6 & 2 & 1.12198 & 0.68454 & 6 & 4 & - & $0.99 \pm 0.85$ \\
\hline Albizia odoratissima (L.f.) Benth. & Mimosaceae & 3 & 2 & 0.12709 & 0.13359 & 3 & 1 & - & $0.85 \pm 0.73$ \\
\hline Allophylus serratus (Roxb.) Kurz & Sapindaceae & 1 & 0 & 0.00127 & - & 1 & 1 & - & $0.00 \pm 0.00$ \\
\hline Atalantia monophylla (L.) Correa & Rutaceae & 10 & 10 & 0.09026 & 0.1235 & 10 & - & - & $0.36 \pm 0.08$ \\
\hline Azadirachta indica A. Juss. & Meliaceae & 17 & 11 & 0.43842 & 0.37163 & 17 & 6 & - & $0.50 \pm 0.04$ \\
\hline Benkara malabarica (Lam.) Tirven. & Rubiaceae & 3 & 10 & 0.02571 & 0.03713 & 3 & - & 7 & $0.06 \pm 0.01$ \\
\hline Borassus flabellifer $\mathrm{L}$. & Arecaceae & 11 & 8 & 1.00083 & 0.71477 & 11 & 3 & - & $0.09 \pm 0.06$ \\
\hline Cadaba trifoliata (Roxb.) Wight \& Arn. & Capparaceae & 22 & 38 & 0.17873 & 0.27522 & 22 & - & 16 & $0.41 \pm 0.31$ \\
\hline Canthium coromandelicum (Burm.f.) Alston & Rubiaceae & 1 & 1 & 0.00385 & 0.00093 & 1 & - & - & $0.00 \pm 0.00$ \\
\hline Canthium dicoccum (Gaertn.) Teijsm. \& Binn. & Rubiaceae & 80 & 100 & 0.75788 & 1.0442 & 80 & - & 20 & $0.48 \pm 0.04$ \\
\hline Cassia fistula $\mathrm{L}$. & Ceasalpiniaceae & 20 & 20 & 0.28415 & 0.35116 & 20 & - & - & $0.66 \pm 0.01$ \\
\hline Cassia roxburghii DC. & Caesalpiniaceae & 4 & 3 & 0.04635 & 0.06781 & 4 & 1 & - & $0.81 \pm 0.18$ \\
\hline Cassia siamea Lam. & Caesalpiniaceae & 4 & 3 & 0.06457 & 0.04633 & 4 & 1 & - & $0.57 \pm 0.04$ \\
\hline Chloroxylon swietenia DC. & Flindersiaceae & 92 & 93 & 1.39999 & 1.43448 & 92 & - & 1 & $0.69 \pm 0.08$ \\
\hline Clausena dentata (Willd.) Roemer & Rutaceae & 9 & 14 & 0.01247 & 0.02238 & 9 & - & 5 & $0.06 \pm 0.02$ \\
\hline Commiphora caudata (Wight \& Arn.) Engle. & Burseraceae & 2 & 2 & 0.00839 & 0.00739 & 2 & - & - & $0.55 \pm 0.50$ \\
\hline Cordia obliqua Willd. & Cordiaceae & 18 & 11 & 0.70557 & 0.48407 & 18 & 7 & - & $1.10 \pm 0.44$ \\
\hline Crateva magna (Lour.) DC. & Capparaceae & 4 & 3 & 0.06613 & 0.08149 & 4 & 1 & - & $1.02 \pm 0.47$ \\
\hline Dalbergia paniculata Roxb. & Papilionaceae & 1 & 6 & 0.14296 & 0.16361 & 1 & - & 5 & $0.00 \pm 0.00$ \\
\hline Diospyros ebenum Koen. & Ebenaceae & 14 & 17 & 0.64463 & 0.71072 & 14 & - & 3 & $0.43 \pm 0.55$ \\
\hline Diospyros ferrea (Willd.) Bakh. & Ebenaceae & 2 & 4 & 0.00349 & 0.01021 & 2 & - & 2 & $0.05 \pm 0.18$ \\
\hline Diospyros montana Roxb. & Ebenaceae & 9 & 8 & 0.16394 & 0.27317 & 9 & 1 & - & $0.82 \pm 0.54$ \\
\hline Drypetes sepiaria (Wight \& Arn.) Pax. \& Hoffm. & Euphorbiaceae & 380 & 322 & 13.9698 & 12.4757 & 380 & 58 & - & $0.59 \pm 0.01$ \\
\hline Ehretia pubescens Benth. & Cordiaceae & 2 & 0 & 0.02987 & - & 2 & 2 & - & $0.00 \pm 0.00$ \\
\hline Euphorbia antiquorum L. & Euphorbiaceae & 97 & 81 & 1.7242 & 1.36972 & 97 & 16 & - & $0.50 \pm 0.27$ \\
\hline Ficus amplissima J.E.Smith & Moraceae & 3 & 4 & 0.56223 & 0.70999 & 3 & - & 1 & $0.82 \pm 0.07$ \\
\hline Ficus benghalensis L. & Moraceae & 5 & 6 & 1.38598 & 1.5592 & 5 & - & 1 & $3.53 \pm 1.17$ \\
\hline Ficus microcarpa L.f. & Moraceae & 3 & 3 & 0.94686 & 1.26031 & 3 & - & 0 & $1.60 \pm 0.87$ \\
\hline Ficus religiosa $\mathrm{L}$. & Moraceae & 2 & 2 & 0.34854 & 0.408 & 2 & - & 0 & $1.70 \pm 0.28$ \\
\hline Flacourtia indica (Burm.f.) Merr. & Flacourtiaceae & 2 & 6 & 0.00596 & 0.01798 & 2 & - & 4 & $0.09 \pm 0.13$ \\
\hline Gardenia resinifera Roth & Rubiaceae & 19 & 26 & 0.13825 & 0.17562 & 19 & - & 7 & $0.46 \pm 0.03$ \\
\hline Glycosmis mauritiana (Lam.) Yuich. Tanaka & Rutaceae & 165 & 352 & 0.19654 & 0.55221 & 165 & - & 187 & $0.48 \pm 0.06$ \\
\hline Gmelina asiatica $\mathrm{L}$ & Verbenaceae & 6 & 7 & 0.12699 & 0.14683 & 6 & - & 1 & $0.27 \pm 0.09$ \\
\hline Jatropha gossypiifolia $L$. & Euphorbiaceae & 0 & 1 & - & 0.00093 & 0 & - & 1 & $0.00 \pm 0.00$ \\
\hline Lannea coromandelica (Houtt.) Merr. & Anacardiaceae & 23 & 26 & 1.06847 & 1.56611 & 23 & - & 3 & $1.06 \pm 1.83$ \\
\hline Lepisanthes tetraphylla (Vahl.) Radlk. & Sapindaceae & 129 & 106 & 1.54835 & 1.7129 & 129 & 23 & - & $0.76 \pm 0.23$ \\
\hline Manilkara hexandra (Roxb.) Dubard & Sapotaceae & 71 & 57 & 8.49337 & 7.94218 & 71 & 14 & - & $1.02 \pm 0.10$ \\
\hline Maytenus emarginata (Willd.) Ding Hou & Celastraceae & 1 & 0 & 0.00161 & - & 1 & 1 & - & $0.00 \pm 0.00$ \\
\hline Memecylon umbellatum Burm.f. & Melastomataceae & 1633 & 1171 & 4.68979 & 4.34299 & 1633 & 462 & - & $0.62 \pm 0.13$ \\
\hline Morinda pubescens J.E. Smith & Rubiaceae & 14 & 16 & 0.338 & 0.20655 & 14 & - & 2 & $0.70 \pm 0.82$ \\
\hline Phyllanthus polyphyllus Willd. & Euphorbiaceae & 2 & 2 & 0.01592 & 0.0215 & 2 & - & - & $0.62 \pm 0.09$ \\
\hline Pleiospermium alatum (Wall. ex Wight. \& Arn.) Sw & Rutaceae & 5 & 5 & 0.01625 & 0.01678 & 5 & - & - & $0.25 \pm 0.14$ \\
\hline Pongamia pinnata (L.) Pierre & Papilionaceae & 72 & 51 & 2.05516 & 2.27028 & 72 & -21 & - & $1.61 \pm 0.36$ \\
\hline Premna serratifolia $\mathrm{L}$. & Verbenaceae & 4 & 4 & 0.38394 & 0.40718 & 4 & - & - & $0.97 \pm 0.21$ \\
\hline Prosopis juliflora (Sw.) DC. & Mimosaceae & 19 & 18 & 0.21923 & 0.30004 & 19 & -1 & - & $0.63 \pm 0.49$ \\
\hline Pterospermum canescens Roxb. & Sterculiaceae & 250 & 208 & 8.87413 & 9.35771 & 250 & -42 & - & $1.10 \pm 0.60$ \\
\hline Sapindus emarginatus Vahl & Sapindaceae & 2 & 1 & 0.05545 & 0.04969 & 2 & -1 & - & $0.00 \pm 0.00$ \\
\hline Sapium insigne (Royle) Trimen & Euphorbiaceae & 9 & 9 & 0.32795 & 0.27098 & 9 & - & 0 & $0.31 \pm 0.67$ \\
\hline Streblus asper Lour. & Moraceae & 0 & 1 & & 0.00385 & 0 & - & 1 & $0.00 \pm 0.00$ \\
\hline Strychnos nux-vomica $\mathrm{L}$. & Loganiaceae & 240 & 178 & 3.57752 & 4.03002 & 240 & -62 & - & $1.16 \pm 0.62$ \\
\hline Sryrchnos potatorum L. f. & Loganiaceae & 9 & 6 & 0.12529 & 0.13491 & 9 & -3 & - & $0.86 \pm 0.11$ \\
\hline Syzygium cumini (L.) Skeels & Myrtaceae & 30 & 27 & 5.85676 & 6.6335 & 30 & -3 & - & $2.03 \pm 1.73$ \\
\hline Tarenna asiatica (L.) Kuntez ex Schumann & Rubiaceae & 36 & 54 & 0.04317 & 0.09468 & 36 & - & 18 & $0.30 \pm 0.28$ \\
\hline Terminalia bellirica (Gaertner) Roxb. & Combretaceae & 2 & 1 & 2.10605 & 1.51698 & 2 & -1 & - & $0.00 \pm 0.00$ \\
\hline Vitex altíssima $\mathrm{L} . \mathrm{f}$. & Verbenaceae & 50 & 45 & 3.05733 & 3.37573 & 50 & -5 & - & $0.89 \pm 0.59$ \\
\hline Walsura trifolia (A.Juss.) Harms & Meliaceae & 1 & 1 & 0.00258 & 0.02246 & 1 & - & - & $0.00 \pm 0.00$ \\
\hline Wrightia tinctoria (Roxb.) R.Br. & Apocyanaceae & 4 & 4 & 0.01009 & 0.01761 & 4 & - & - & $0.65 \pm 0.07$ \\
\hline
\end{tabular}



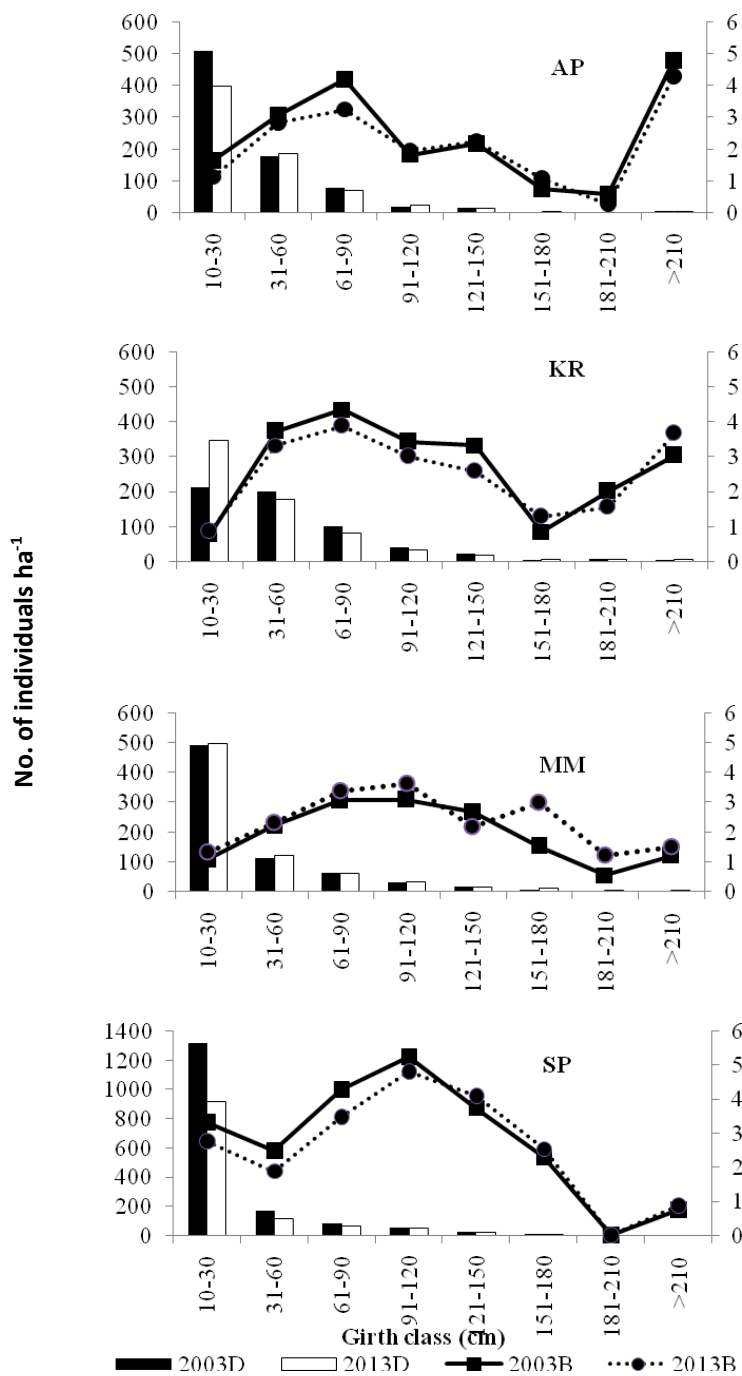

Figure 2. Decadal changes (2003 \& 2013) in basal area (B) and tree density (D) by tree girth class in Araiyapatti (AP), Karisakkadu (KR), Maramadakki (MM) and Shanmuganathapuram (SP) tropical dry evergreen forest sites

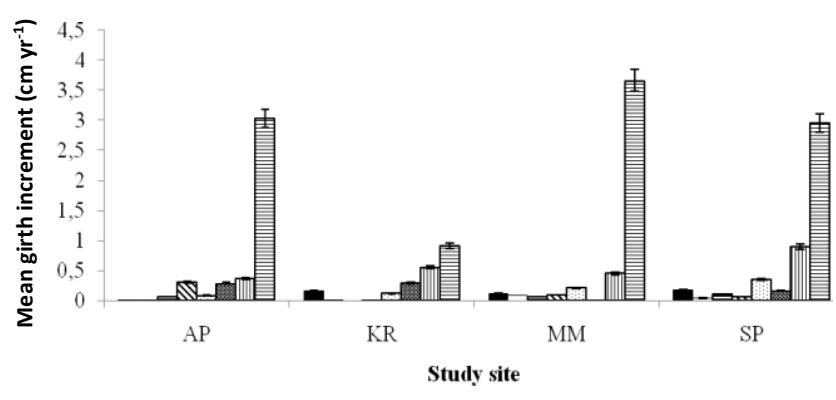

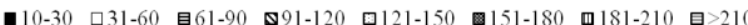

Figure 3. Mean girth increment $\left(\mathrm{cm} \mathrm{yr}^{-1}\right)$ of trees by girth classes in four study sites - (AP, KR, MM and SP)

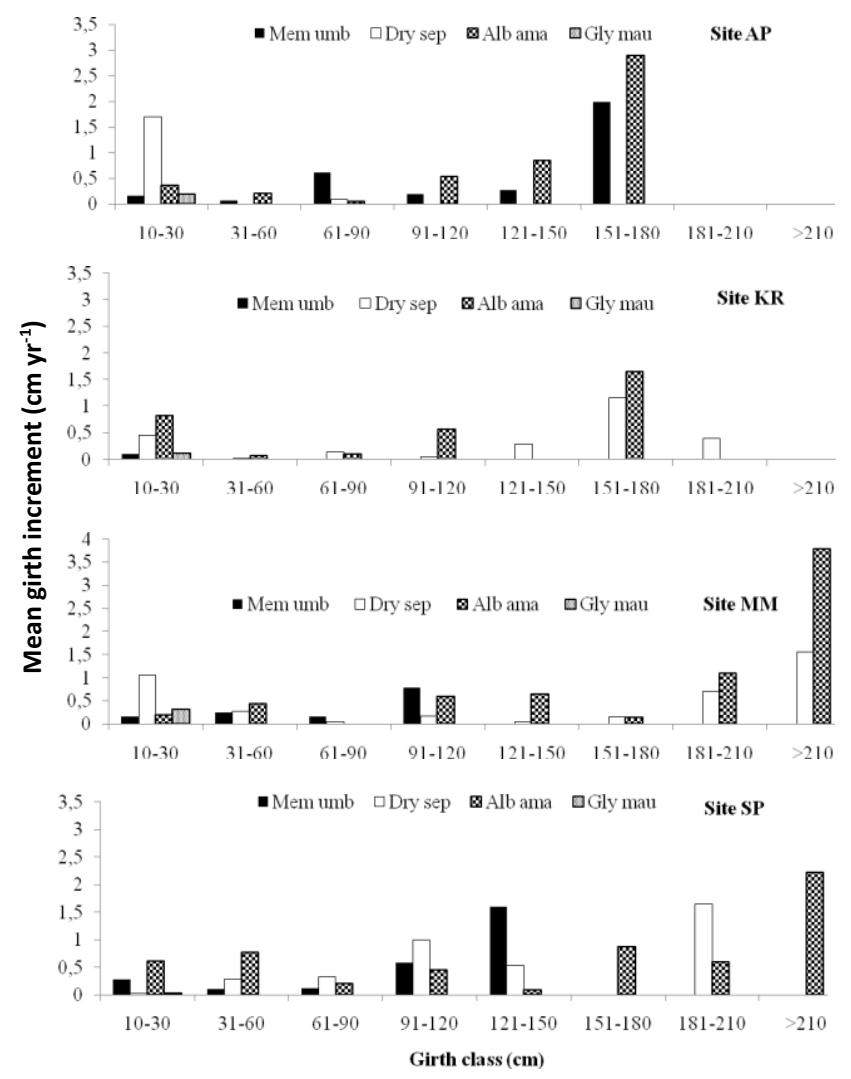

Figure 4. Comparative mean girth increment $\left(\mathrm{cm} \mathrm{yr}^{-1}\right)$ by girth classes for four abundant tree species $(\geq 10 \mathrm{gbh})$ enumerated in all the four sites (from left to right): (a) Memecylon umbellatum, (b) Drypetes sepiaria, (c) Albizia amara, (d) Glycosmis mauritiana

This due to selective felling trees for temple construction and greater resource extraction, such as fuelwood, fodder collection, and grazing pressure. This kind of disturbances leads to thinning of the woody layer and change the forest microclimate, which in turn might impair regeneration process of tree species resulting in low abundance. A marginal reduction in the tree density from 3825 stems in 1996 to 3814 stems in the 1999 Kolli hills, with an annual mortality rate of $0.73 \%$ was reported by Sundaram and Parthasarathy (2002) across the four sites. Phillips et al. (1994) reported mortality rate of 1 to $3 \% \mathrm{yr}^{-1}$ in Asian rainforests. Manokaran and Kochummen (1987) reported that tree density decreased between the years 1947-1951 in Sungei Menyala, Malaysia. The maximum recruitment rate was registered at site $\mathrm{KR}\left(21.8 \% \mathrm{yr}^{-1}\right)$ and $\mathrm{MM}\left(11.5 \% \mathrm{yr}^{-}\right.$ $\left.{ }^{1}\right)$ which are the less disturbed sites, but the recruitment rate was less in the other disturbed sites AP $\left(9.1 \% \mathrm{yr}^{-1}\right)$ and SP $\left(5.1 \% \mathrm{yr}^{-1}\right)$ (Table 3$)$. This could be assigned to human disturbance as well as natural disturbances that facilitate favorable conditions for recruitment of new individuals or the growth of pre-existing ones in the understory species. However, the majority of saplings in the understorey of tropical rainforests grow in the shade (Chazdon and Fetcher 1984; Clark and Clark, 1999) and the trajectories to the canopy can be long (Clark and Clark 2001; Brienen and 
Zuidema 2006) putting strong selection pressure on traits that increase survival in the shade. Elevated recruitment rates were reported after periods of acute disturbance (Lugo and Scatena 1996; Boucher and Mallona 1997) or chronic disturbance, such as in especially dry years (Condit et al. 1996), in secondary stands (plot 2 in Milton et al. 1994; selectively logged area (in Elouard et al. 1997) and/or forest edges (Laurence et al. 1998). Tree turnover rate ranged from 9.7 in site $\mathrm{MM}$ to $25.4 \% \mathrm{yr}^{-1}$ in site $\mathrm{SP}$.

The calculated tree turnover rate (mean of mortality and recruitment rate) for stems $\geq 10 \mathrm{~cm}$ gbh ranged from $9.7 \%$ in site MM to $25.4 \%$ in site SP (Table 3). The turnover rates of tropical forests are often said to be high, with mortality rates $>1 \%$ and sometimes $>2 \%$ per year (Lieberman and Lieberman 1987; Manokaran and Kochummen 1987; Swaine et al. 1987; Proctor et al. 1989; Phillips et al. 1994) and Mani (2006) also reported turnover rate range of 1.1 to $1.6 \% \mathrm{yr}^{-1}$ over three years (2003-2006) at five inland tropical dry evergreen forests of peninsular India. However, over a longer interval time the precision of recruitment and mortality estimates declines as more trees would have recruited and died undetected in the time interval (Phillips et al. 2004). In other tropical forests, a turnover rate of $0.68 \%$ was reported in wet evergreen forest of Kolli hills, Eastern Ghats (Sundaram and Parthasarathy 2002) and this is low when compared to neotropical (1.84\% in Añangu, Ecuador- Korning and Balslev 1994; 0.91\% in Reserva Ducke, Brazil- Rankin de Merona et al. 1990; and $2.15 \%$ in La Selva, Costa Rica-Lieberman and Lieberman 1987) and Asian tropical $(0.89 \%$ in Sungei Menyala, Malaysia-Manokaran and Kochummen 1987; $1.89 \%$ in Pasoh, Malaysia-Condit et al. 1992 and 1.36\% in Lambir, Malaysia-Hall 1991) forests.

In summary, there has been a considerable change in tree diameter increment, mortality and recruitment rate over a decade in four inland Indian tropical dry evergreen forest sites. These long-term studies are important for understanding the tropical forest tree dynamics; it is vital to know the forest status especially those of growth, mortality and recruitment rate and also this data will useful further research. Tree diversity decreased in sites AP and SP, whereas other two sites moderately increased this indicate forest threatened by disturbance multiple reasons (Clearing the trees inside the forest, Grazing by goats, Road construction for the temple (width), and Cultural attachment of local people), those disturbances promoting tree diameter increment. Further, we suggested the need for long-term monitoring studies to get deeper insights in understanding the forest growth rate and to ascertain the role of trees in forest dynamics on a long-term basis, and, in turn, for forest management.

\section{ACKNOWLEDGEMENTS}

Dr. E. Pandian thanks DST-SERB-N PDF (PDF/2015/ 000874) for financial support. We also thank Dr. M. Anbarashan, Pondicherry University for valuable suggestions and Dr. Satyam Verma for help in map preparation. We express our gratitude to the anonymous reviewers for their valuable comments to improve the manuscript.

\section{REFERENCES}

Anbarashan M, Parthasarathy N. 2012. Tree diversity and forest stand structure along disturbance gradients in Indian tropical dry evergreen forest. Ecotropica 18: 119-136.

Ayyappan N, Parthasarathy N. 1999. Biodiversity inventory of trees in a large-scale permanent plot of tropical evergreen forest at Varagalaiar, Anamalais, Western Ghats, India. Biodivers Conserv 8: 1533-1554.

Baithalu S, Anbarashan M, Parthasarathy N. 2012. Changes in tree diversity and stand structure of two tropical dry evergreen forests on the Coromandel Coast of peninsular India over a decade (20012011). Int J Ecol Env Sci 38: 87-96.

Baithalu S, Anbarashan M, Parthasarathy N. 2013. Two-decadal changes in forest structure and tree diversity in a tropical dry evergreen forest on the Coromandel Coast of India. Trop Ecol 54: 397-403.

Baker TR, Phillips OL, Malhi Y, Almeida S, Arroyo L, Di Fiore A .2004. Increasing biomass in Amazonian forest plots. Philos Trans R Soc Lond B: Biol Sci 359: 353-365.

Bhat DM, Naik MB, Patagar SG, Hegde GT, Kanade YG, Hegde GN. 2000. Forest dynamics in tropical rain forests of Uttara Kannada district in Western Ghats, India. Curr Sci 79: 975-985.

Boucher DH, Mallona MA. 1997. Recovery of the rainforest tree Vochysia ferruginea over 5 years following Hurricane Joan in Nicaragua: a preliminary population projection matrix. For Ecol Manage 91: 195-204.

Brienen RJ, Zuidema PA. 2006. Lifetime growth patterns and ages of Bolivian rain forest trees obtained by tree ring analysis. J Ecol 94: 481-493.

Chapman CA, Chapman LJ. 1990. Density and growth rate of some tropical dry forest trees: comparisons between successional forest types. Bull Torrey Bot Club 117: 226-231.

Chazdon RL, Fetcher N. 1984. Photosynthetic light environments in a lowland tropical rainforest in Costa Rica. J Ecol 72: 553-564.

Chittibabu CV, Parthasarathy N. 2000. Attenuated tree species diversity in human-impacted tropical evergreen forest sites at Kolli hills, Eastern Ghats, India. Biodivers Conserv 9: 1493-1519.

Chojnacky DC. 2001. On FIA variables for ecological use. In: Reams GA, McRoberts RE, Van Deusen PC (eds.). Proceedings of the second annual Forest Inventory and Analysis Symposium, 2000 October 1718; Salt Lake City, UT. U.S. Department of Agriculture, Forest Service, Southern Research Station, Asheville, NorthCarolina, USA.

Clark DA, Clark DB. 1994. Climate-induced annual variation in canopy tree growth in a Costa Rican tropical rain forest. J Ecol 82: 865-872.

Clark DA, Clark DB. 1999. Assessing the growth of tropical rain forest trees: issues for forest modeling and management. Ecol Appl 9: 981997.

Clark DA, Clark DB. 2001. Getting to the canopy: tree height growth in a neotropical rain forest. Ecology 82: 1460-1472.

Clark DA, Piper SC, Keeling CD, Clark DB. 2003. Tropical rain forest tree growth and atmospheric carbon dynamics linked to inter-annual temperature variation during 1984-2000. Proc Natl Acad Sci USA 100: 5852-5857.

Clark DB, Clark DA, Oberbauer SF. 2010. Annual wood production in a tropical rain forest in NE Costa Rica linked to climatic variation but not to increasing CO2. Glob Chang Biol 16: 747-759.

Condit R, Hubbell SP, Foster RB. 1992. Short-term dynamics of a neotropical forest. Bioscience 822-828.

Dong SX, Davies SJ, Ashton PS, Bunyavejchewin S, Supardi MN, Kassim AR. 2012. Variability in solar radiation and temperature explains observed patterns and trends in tree growth rates across four tropical forests. Proc R Soc Lond B: Bio Sci 279: 3923-3931.

Elouard C, Pascal JP, Pelissier R, Ramesh BR, Houllier F, Durand M. 1997. Monitoring the structure and dynamics of a dense moist evergreen forest in the Western Ghats (Kodagu District, Karnataka, India). Trop Ecol 38: 193-214.

Fashing PJ, Forrestel A, Scully C, Cords M. 2004. Long-term tree population dynamics and their implications for the conservation of the Kakamega Forest, Kenya. Biodivers Conserv 13: 753-771. 
Feeley KJ, Joseph Wright S, Supardi N, Kassim AR, Davies SJ. 2007. Decelerating growth in tropical forest trees. Ecol Lett 10: 461-469.

Felfili JM. 1995. Growth, recruitment and mortality in the Gama gallery forest in central Brazil over a six-year period (1985-1991). J Trop Ecol 11: 67-83.

Felfili JM, Rezende AV, Júnior MCDS, Silva MA. 2000. Changes in the floristic composition of cerrado sensu stricto in Brazil over a nineyear period. J Trop Ecol 16: 579-590.

Gamble JS, Fischer CEC. 1915-1935. Flora of the Presidency of Madras. Vols. I-III. Adlard and Son Ltd., London.

Hall P. 1991. Structure, stand dynamics and species compositional change in three mixed dipterocarp forests of northwest Borneo. Ph.D. Thesis. Boston Univ., Boston, MA. USA.

Harcombe PA. 1987. Tree life tables. Bioscience: 557-568.

He F, Duncan RP. 2000. Density-dependent effects on tree survival in an old-growth Douglas fir forest. J Trop Ecol 88: 676-688.

Henry AN, Kumari GR, Chitra V. 1987. Flora of Tamil Nadu, India Ser. 1, Vol. 2. Botanical Survey of India, Coimbatore.

Henry AN, Chitra V, Balakrishnan NP. 1989. Flora of Tamil Nadu, India Ser. 1, Vol. 3. Botanical Survey of India, Coimbatore.

Herwitz SR, Young SS. 1994. Mortality, recruitment, and growth rates of montane tropical rainforest canopy trees on Mount Bellenden-Ker, Northeast Queensland, Australia. Biotropica 26: 350-361.

Hitimana J, Kiyiapi JL, Njunge JT. 2004. Forest structure characteristics in disturbed and undisturbed sites of Mt. Elgon Moist Lower Montane Forest, western Kenya. For Ecol Manage 194: 269-291.

Holtum JA, Winter K. 2010. Elevated $\left[\mathrm{CO}_{2}\right]$ and forest vegetation: more a water issue than a carbon issue? Funct Plant Biol 37: 694-702.

Keenan TF, Hollinger DY, Bohrer G, Dragoni D, Munger JW, Schmid HP, Richardson AD. 2013. Increase in forest water-use efficiency as atmospheric carbon dioxide concentrations rise. Nature 499: 324-327.

Korning J, Balslev H. 1994. Growth and mortality of trees in Amazonian tropical rain forest in Ecuador. J Veg Sci 5: 77-86.

Kunstler G, Albert CH, Courbaud B, Lavergne S, Thuiller W, Vieilledent G. 2011. Effects of competition on tree radial-growth vary in importance but not in intensity along climatic gradients. J Ecol 99: 300-312.

Lang GE, Knight DH. 1983. Tree growth, mortality, recruitment, and canopy gap formation during a 10 -year period in a tropical moist forest. Ecology 1075-1080.

Laurance WF, Ferreira LV, Rankin-de Merona JM, Laurance SG. 1998 Rain forest fragmentation and the dynamics of Amazonian tree communities. Ecology 79: 2032-2040.

Laurance WF, Oliveira AA, Laurance SG, Condit R, Nascimento HE, Sanchez-Thorin AC. 2004. Pervasive alteration of tree communities in undisturbed Amazonian forests. Nature 428: 171-175.

Lewis SL, Lloyd J, Sitch S, Mitchard ET, Laurance WF. 2009. Changing ecology of tropical forests: evidence and drivers. Annu. Rev Ecol Evol Syst 40: 529-549.

Lewis SL, Phillips OL, Baker TR, Lloyd J, Malhi Y, Almeida S. 2004. Concerted changes in tropical forest structure and dynamics: evidence from 50 South American long-term plots. Philos Trans R Soc B: Bio Sci 359: 421-436.

Lieberman D, Lieberman M. 1987. Forest tree growth and dynamics at La Selva, Costa Rica (1969-1982). J Trop Ecol 3: 347-358.

Lieberman D, Lieberman M, Peralta R, Hartshorn GS. 1985. Mortality patterns and stand turnover rates in a wet tropical forest in Costa Rica. J Ecol 915-924.

Lines ER, Coomes DA, Purves DW. 2010. Influences of forest structure, climate and species composition on tree mortality across the eastern US. PLoS One 5 (10): e13212. DOI: 10.1371/journal.pone.0013212

Lloyd J, Farquhar GD. 2008. Effects of rising temperatures and [CO2] on the physiology of tropical forest trees. Philos Trans R Soc B: Bio Sci 363: 1811-1817.

Lugo AE, Scatena FN. 1996. Background and catastrophic tree mortality in tropical moist, wet, and rain forests. Biotropica 585-599.

Mani S, Parthasarathy N. 2009. Tree population and above-ground biomass changes in two disturbed tropical dry evergreen forests of peninsular India. Trop Ecol 50: 249.

Mani S. 2006. Biodiversity assessment of trees and short-term population changes in five inland tropical dry evergreen forests of peninsular India. [Dissertation]. Pondicherry University, India.
Mani S, Parthasarathy N. 2005. Biodiversity assessment of trees in five inland tropical dry evergreen forests of peninsular India. Syst Biodivers 3: 1-12.

Manokaran N, Kochummen KM. 1987. Recruitment, growth, and mortality of tree species in a lowland dipterocarp forest in Peninsular Malaysia. J Trop Ecol 3: 315-330.

Matthew KM. 1991. An Excursion Flora of Central Tamil Nadu, India. Oxford and I.B.H. Publishers, New Delhi.

Metcalf CJE, Horvitz CC, Tuljapurkar S, Clark DA. 2009. A time to grow and a time to die: a new way to analyze the dynamics of size, light, age, and death of tropical trees. Ecology 90: 2766-2778.

Nair NC, Henry AN. 1983. Flora of Tamil Nadu, India. Ser. 1, Vol. 1. Botanical Survey of India. Coimbatore.

Newbery DM, Kennedy DN, Petol GH, Madani L, Ridsdale CE. 1999. Primary forest dynamics in lowland dipterocarp forest at Danum Valley, Sabah, Malaysia, and the role of the understorey. Philos Trans R Soc Lond B: Bio Sci 354: 1763-1782.

Pandian E, Parthasarathy N. 2016. Decadal (2003-2013). Changes in liana diversity, abundance and aboveground biomass in four inland tropical dry evergreen forest sites of peninsular India. J For Res 27: 133-146.

Parthasarathy N. 1999. Tree diversity and distribution in undisturbed and human-impacted sites of tropical wet evergreen forest in southern Western Ghats, India. Biodivers Conserv 8: 1365-1381.

Pascal JP, Pelissier R. 1996. Structure and floristic composition of a tropical evergreen forest in south-west India. J Trop Ecol 12: 191214.

Pascal JP, Ramesh BR. 1987. A Field Key to the Trees and Lianas of the Western Ghats (India). Institute Francais de Pondichery, Travaux de la section Scientifique et Technique, Tome XXIII, Pondicherry.

Phillips OL, Baker TR, Arroyo L, Higuchi N, Killeen TJ, Laurance WF. 2004. Pattern and process in Amazon tree turnover, 1976-2001. Philos Trans R Soc 359: 381-407.

Phillips OL, Hall P, Gentry AH, Sawyer SA, Vasquez R. 1994. Dynamics and species richness of tropical rain forests. Proc Natl Acad Sci 91: 2805-2809.

Phillips OL, Lewis SL, Baker TR, Chao KJ, Higuchi N. 2008. The changing Amazon forest. Philos. Trans. R. Soc. B: Bio Sci 363: 18191827.

Proctor J, Lee YF, Langley AM, Munro WRC, Nelson T. 1988. Ecological studies on Gunung Silam, a small ultrabasic mountain in Sabah, Malaysia. I. Environment, forest structure, and floristics. J Ecol 320-340.

Rankin-de-Merona JM, Hutchings RW, Lovejoy TE. 1990. Tree mortality and recruitment over a five-year period in undisturbed upland rainforest of the Central Amazon.In: Gentry AH. (ed). Four Neotropical Rainforests. Yale Univ. Press, New Haven.

Schmidt R, Weaver PL. 1981. Tree diameter increment in the subtropical moist life zone of Puerto Rico. Turrialba 31: 261-263.

Sheil D, May RM. 1996. Mortality and recruitment rate evaluations in heterogeneous tropical forests. J Ecol 84: 91-100.

Sheil D, Burslem DF, Alder D. 1995. The interpretation and misinterpretation of mortality rate measures. J Ecol: 331-333.

Sheil D, Jennings S, Savill P. 2000. Long-term permanent plot observations of vegetation dynamics in Budongo, a Ugandan rain forest. J Trop Ecol 16: 865-882.

Sukumar R, Dattaraja HS, Suresh HS, Radhakrishnan J, Vasudeva R, Nirmala S, Joshi NV. 1992. Long-term monitoring of vegetation in a tropical deciduous forest in Mudumalai, southern India. Curr Sci 62: 608-616.

Sukumar R, Suresh HS, Dattaraja HS, Joshi NV. 1998. Dynamics of a tropical deciduous forest: population changes (1988 through 1993) in a 50-ha plot at Mudumalai, southern India. In: Dallmeier F, Comiskey JA. (eds). Forest Biodiversity Research, Monitoring and Modeling: Conceptual Background and Old World Case Studies. Parthenon Publishing, Paris.

Sundaram B, Parthasarathy N. 2002. Tree growth, mortality, and recruitment in four tropical wet evergreen forest sites of the Kolli hills, eastern ghats, India. Trop Ecol 43: 275-286.

Swaine MD, Lieberman D, Putz FE. 1987. The dynamics of tree populations in tropical forest: a review. J Trop Ecol 3: 359-366.

Taylor DM, Hamilton AC, Whyatt JD, Mucunguzi P, Bukenya-Ziraba R. 1996. Stand dynamics in Mpanga Research Forest Reserve, Uganda, 1968-1993. J Trop Ecol 12: 583-597.

Zarr JH. 2006. Biostatistical analysis. Prentice Hall, New Jersey. 
Table S1. Past and present site disturbance score status (1- ranked as rare: 2-occasional: 3-frequent) of four inland tropical dry evergreen forest sites, Araiyapatti (AP), Karisakkadu (KR), Maramadakki (MM) and Shanmuganathapuram (SP) in peninsular India

\begin{tabular}{|c|c|c|c|c|c|c|c|c|}
\hline \multirow{2}{*}{ Attributes } & \multicolumn{2}{|c|}{$\mathbf{A P}$} & \multicolumn{2}{|c|}{ KR } & \multicolumn{2}{|c|}{ MM } & \multicolumn{2}{|c|}{ SP } \\
\hline & 2003 & 2013 & 2003 & 2013 & 2003 & 2013 & 2003 & 2013 \\
\hline \multicolumn{9}{|l|}{ Site encroachment (land use within the forest) } \\
\hline Temple construction & 1 & 2 & 2 & 3 & 3 & 3 & 2 & 2 \\
\hline Bridle path use & 1 & 3 & 2 & 2 & 3 & 3 & 3 & 3 \\
\hline \multicolumn{9}{|l|}{ Temple visitors impact: area used for } \\
\hline Vehicle parking (area occupied) & 1 & 2 & 3 & 3 & 2 & 2 & 3 & 3 \\
\hline Cooking & 1 & 2 & 3 & 3 & 3 & 2 & 2 & 3 \\
\hline Festive occasion use & 1 & 3 & 2 & 2 & 3 & 3 & 2 & 3 \\
\hline Grazing (cattle/goat) & 2 & 3 & 2 & 2 & 3 & 3 & 2 & 2 \\
\hline Culture attachment of local people & 1 & 2 & 2 & 2 & 3 & 3 & 2 & 3 \\
\hline \multicolumn{9}{|l|}{ Resource removal } \\
\hline Firewood & 1 & 1 & 1 & 1 & 2 & 1 & 1 & 2 \\
\hline Timber & 1 & 2 & 1 & 1 & 1 & 1 & 1 & 2 \\
\hline Other: medicinal plants, edible fruits and soil & 1 & 2 & 1 & 1 & 2 & 2 & 2 & 2 \\
\hline Nearest habitation \& people's forest dependence & 1 & 2 & 2 & 2 & 3 & 3 & 3 & 3 \\
\hline Approach road to temple (width) & 1 & 2 & 2 & 2 & 3 & 3 & 3 & 3 \\
\hline Fodder (native forest species) collection & 0 & 3 & 0 & 2 & 0 & 2 & 0 & 2 \\
\hline Habitat fragmentation & 0 & 2 & 0 & 1 & 0 & 1 & 0 & 2 \\
\hline Solid waste dumping (plastic, polythene, glass, rexin) & 0 & 2 & 0 & 1 & 0 & 1 & 0 & 2 \\
\hline Ground clearing for temple related work & 0 & 1 & 0 & 1 & 0 & 1 & 0 & 1 \\
\hline Total score & 13 & 34 & 23 & 29 & 31 & 33 & 26 & 38 \\
\hline
\end{tabular}

Note: Pandian and Parthasarathy (2016) 
Table S2. Summary of density (stems ha $\left.{ }^{-1}\right)$ and mean girth increment $\left(\mathrm{cm} \mathrm{yr}^{-1}\right)$ of all tree species $(\geq 10 \mathrm{gbh})$ by girth class during 2003 and 2013 inventories in four inland tropical dry evergreen forest sites AP, KR MM and SP. Data were pooled

\begin{tabular}{|c|c|c|c|c|c|c|c|c|c|c|c|c|c|c|c|c|c|c|c|c|c|c|c|c|c|}
\hline \multirow{2}{*}{ Species name } & \multirow{2}{*}{ Family } & \multicolumn{8}{|c|}{ Tree density by girth class - 2003} & \multicolumn{8}{|c|}{ Tree density by girth class -2013} & \multicolumn{8}{|c|}{$\begin{array}{c}\text { Mean girth increment rate of trees }\left(\mathrm{cm} \mathrm{yr}^{-1}\right) \text { by girth } \\
\text { class }\end{array}$} \\
\hline & & $10-30$ & $31-60$ & $61-90$ & $\begin{array}{l}91- \\
120\end{array}$ & $\begin{array}{l}121- \\
150\end{array}$ & $\begin{array}{l}151- \\
180\end{array}$ & $\begin{array}{l}181- \\
210\end{array}$ & $>210$ & $10-30$ & $31-60$ & $61-90$ & $\begin{array}{l}91- \\
120\end{array}$ & $\begin{array}{l}121- \\
150\end{array}$ & $\begin{array}{l}151- \\
180\end{array}$ & $181-211)$ & $>2101$ & $10-30 \mathrm{~cm}$ & n 31-60 & 0 $61-90$ & $91-120$ & $121-150$ & $151-180$ & $181-210$ & $0>210$ \\
\hline Acacia leucophloea (Roxb.) Willd. & Mimosaceae & 1 & 0 & 2 & 0 & 0 & 0 & 0 & 0 & 2 & 1 & 1 & 0 & 0 & 0 & 0 & 0 & 0.07 & 0 & 0.65 & 0 & 0 & 0 & 0 & 0 \\
\hline Albizia amara (Roxb.) Boivin & Mimosaceae & 53 & 29 & 26 & 25 & 17 & 6 & 4 & 4 & 44 & 29 & 15 & 22 & 16 & 11 & 3 & 4 & 0.02 & 0.11 & 0.18 & 0.43 & 0.03 & 0.39 & 0.42 & 1.07 \\
\hline Albizia lebbeck (L.) Benth. & Mimosaceae & 1 & 0 & 0 & 0 & 3 & 0 & 0 & 1 & 0 & 0 & 0 & 0 & 1 & 0 & 0 & 1 & 0 & 0 & 0 & 0 & 0.75 & 0 & 0 & 1.1 \\
\hline Albizia odoratissima (L.f.) Benth. & Mimosaceae & 0 & 1 & 1 & 1 & 0 & 0 & 0 & 0 & 0 & 0 & 1 & 1 & 0 & 0 & 0 & 0 & 0 & 0 & 0.74 & 0.98 & 0 & 0 & 0 & 0 \\
\hline Allophylus serratus (Roxb.) Kurz & Sapindaceae & 1 & 0 & 0 & 0 & 0 & 0 & 0 & 0 & 0 & 0 & 0 & 0 & 0 & 0 & 0 & 0 & 0 & 0 & 0 & 0 & 0 & 0 & 0 & 0 \\
\hline Atalantia monophylla (L.) Correa & Rutaceae & 9 & 0 & 1 & 0 & 0 & 0 & 0 & 0 & 6 & 3 & 1 & 0 & 0 & 0 & 0 & 0 & 0.16 & 0 & 0.4 & 0 & 0 & 0 & 0 & 0 \\
\hline Azadirachta indica A. Juss. & Meliaceae & 7 & 5 & 2 & 3 & 0 & 0 & 0 & 0 & 3 & 4 & 2 & 2 & 0 & 0 & 0 & 0 & 0.35 & 0.48 & 0.22 & 0.54 & 0 & 0 & 0 & 0 \\
\hline Benkara malabarica (Lam.) Tirven. & Rubiaceae & 1 & 0 & 1 & 1 & 0 & 0 & 0 & 0 & 8 & 1 & 0 & 1 & 0 & 0 & 0 & 0 & 0.23 & 0 & 0 & 0.35 & 0 & 0 & 0 & 0 \\
\hline Borassus flabellifer $\mathrm{L}$. & Arecaceae & 0 & 0 & 1 & 9 & 1 & 0 & 0 & 0 & 0 & 0 & 1 & 7 & 0 & 0 & 0 & 0 & 0 & 0 & 0.1 & 0.17 & 0 & 0 & 0 & 0 \\
\hline Cadaba trifoliata (Roxb.) Wight \& Arn. & Capparaceae & 11 & 7 & 3 & 0 & 0 & 1 & 0 & 0 & 22 & 11 & 6 & 0 & 0 & 1 & 0 & 0 & 0.35 & 0.28 & 0.14 & 0 & 0 & 1.35 & 0 & 0 \\
\hline Canthium coromandelicum (Burm.f.) Alston & Rubiaceae & 1 & 0 & 0 & 0 & 0 & 0 & 0 & 0 & 1 & 0 & 0 & 0 & 0 & 0 & 0 & 0 & 0.45 & 0 & 0 & 0 & 0 & 0 & 0 & 0 \\
\hline Canthium dicoccum (Gaertn.) Teijsm. \& Binn. & Rubiaceae & 31 & 47 & 2 & 0 & 0 & 0 & 0 & 0 & 41 & 54 & 5 & 0 & 0 & 0 & 0 & 0 & 0.34 & 0.29 & 0.7 & 0 & 0 & 0 & 0 & 0 \\
\hline Cassia fistula $\mathrm{L}$. & Ceasalpiniacea & 8 & 10 & 1 & 1 & 0 & 0 & 0 & 0 & 8 & 6 & 5 & 1 & 0 & 0 & 0 & 0 & 0.58 & 0.04 & 0.03 & 0.15 & 0 & 0 & 0 & 0 \\
\hline Cassia roxburghii DC. & Caesalpiniaceat & 2 & 1 & 1 & 0 & 0 & 0 & 0 & 0 & 0 & 1 & 2 & 0 & 0 & 0 & 0 & 0 & 0 & 1.15 & 1.02 & 0 & 0 & 0 & 0 & 0 \\
\hline Cassia & Caesalpiniacea & 0 & 0 & 0 & 0 & 0 & 0 & 0 & 0 & 2 & 0 & 1 & 0 & 0 & 0 & 0 & 0 & 0 & 0 & 0 & 0 & 0 & 0 & 0 & 0 \\
\hline Chloroxylon swietenia DC. & Flindersiaceae & 48 & 26 & 12 & 4 & 1 & 1 & 0 & 0 & 42 & 35 & 20 & 5 & 0 & 1 & 0 & 0 & 0.02 & 0.01 & 0.24 & 0.64 & 0 & 0.4 & 0 & 0 \\
\hline Clausena & Rutaceae & 9 & 0 & 0 & 0 & 0 & & 0 & 0 & 14 & 0 & 0 & 0 & 0 & 0 & 0 & 0 & 20 & 0 & 0 & 0 & 0 & 0 & 0 & 0 \\
\hline (Wight \& Arn.) Engle. & Burser & 1 & 1 & 0 & 0 & 0 & 0 & 0 & 0 & 2 & 0 & 0 & 0 & 0 & 0 & 0 & 0 & 0.25 & 0 & 0 & 0 & 0 & 0 & 0 & 0 \\
\hline Cordia obliqua & Cordiace & 0 & 0 & 4 & 8 & 4 & 0 & 1 & 0 & 0 & 1 & 5 & 2 & 2 & 0 & 1 & 0 & 0 & 0 & 0.88 & 1.16 & 0.85 & 0 & 1.33 & 0 \\
\hline Cratev & Cappa & 3 & 0 & 1 & 0 & 0 & 0 & 0 & 0 & 1 & 1 & 1 & 0 & 0 & 0 & 0 & 0 & 0.08 & 0 & 0.75 & 0 & 0 & 0 & 0 & 0 \\
\hline Dalb & Papilio & 0 & 0 & 0 & 0 & 1 & 0 & 0 & 0 & 5 & 0 & 0 & 0 & 1 & 0 & 0 & 0 & 0 & 0 & 0 & 0 & 0.6 & 0 & 0 & 0 \\
\hline Diospy & Ebenac & 5 & 3 & 1 & 2 & & & 0 & & 8 & 4 & 1 & 0 & 2 & 2 & 0 & 0 & 0.59 & 0.85 & 1.11 & 0 & 0.95 & 0.97 & 0 & 0 \\
\hline Diospyros ferrea (Willd.) Bakh. & Ebenaceae & 2 & 0 & 0 & 0 & 0 & 0 & 0 & 0 & 3 & 1 & 0 & 0 & 0 & 0 & 0 & 0 & 0.16 & 0 & 0 & 0 & 0 & 0 & 0 & 0 \\
\hline Diospyros montana Roxb. & Ebenace & 6 & 2 & 0 & 0 & 1 & 0 & 0 & & 5 & 2 & 0 & 0 & 1 & 0 & 0 & 0 & 0.33 & 0.3 & 0 & 0 & 0.59 & 0 & 0 & 0 \\
\hline ght \& Arn.) Pax. \& Hoffm. & Euphorbiaceae & 67 & 133 & 78 & 58 & 29 & 6 & 6 & 3 & 55 & 103 & 78 & 37 & 31 & 8 & 8 & 2 & 0.08 & 0.03 & 0.15 & 0.08 & 0.08 & 0.63 & 0.25 & 1.7 \\
\hline Ehretia pu & Cordiaceae & 1 & 0 & 0 & 0 & 1 & 0 & 0 & & 0 & 0 & 0 & 0 & 0 & & & 0 & 0 & 0 & 0 & 0 & 0 & 0 & 0 & 0 \\
\hline Euphor & Euphorbiaceae & 27 & 46 & 23 & 1 & 0 & 0 & 0 & 0 & 30 & 31 & 19 & 1 & 0 & 0 & 0 & 0 & 0.32 & 0.05 & 0.37 & 0.95 & 0 & 0 & 0 & 0 \\
\hline Ficus al & e & 0 & 0 & 1 & 1 & 0 & 0 & 0 & 1 & 0 & 1 & 1 & 1 & 0 & 0 & 0 & 1 & 0 & 0 & 0.7 & 2.05 & 0 & 0 & 0 & 2 \\
\hline Ficus $b$ & $\mathrm{M}$ & 1 & 0 & 0 & 1 & 0 & 1 & 0 & & 2 & 0 & 0 & 1 & 0 & 1 & 0 & 2 & 0.89 & 0 & 0 & 0.3 & 0 & 0.55 & 0 & 2.25 \\
\hline Ficus microcarpa L.f. & Moraceae & 0 & 0 & 1 & 0 & 0 & 0 & 0 & 2 & 0 & 0 & 1 & 0 & 0 & 0 & 0 & 2 & 0 & 0 & 2.4 & 0 & 0 & 0 & 0 & 1.96 \\
\hline Ficus religiosa $\mathrm{L}$. & Moraceae & 0 & 0 & 0 & 0 & 1 & 1 & 0 & & 0 & 0 & 0 & 0 & 1 & 1 & 0 & 0 & 0 & 0 & 0 & & 1 & 1.4 & 0 & 0 \\
\hline Flacourtia indica (Burm.f.) Merr. & aceae & 2 & 0 & 0 & 0 & 0 & 0 & 0 & 0 & 6 & 0 & 0 & 0 & 0 & 0 & 0 & 0 & 0.35 & 0 & 0 & 0 & 0 & 0 & 0 & 0 \\
\hline Gardenia resinifera Roth & Rubiaceae & 13 & 3 & 3 & 0 & 0 & 0 & 0 & 0 & 18 & 6 & 2 & 0 & 0 & 0 & 0 & 0 & 0.39 & 0.41 & 0.53 & 0 & 0 & 0 & 0 & 0 \\
\hline Glycosmis mauritiana (Lam.) Yuich. Tanaka & & 164 & 1 & 0 & 0 & 0 & 0 & 0 & 0 & 348 & 4 & 0 & 0 & 0 & 0 & 0 & 0 & 0.2 & 0.16 & 0 & 0 & 0 & 0 & 0 & 0 \\
\hline Gmelina $a$. & Verbenaceae & 1 & 1 & 0 & 2 & 1 & 0 & 1 & 0 & 1 & 3 & 0 & 2 & 0 & 0 & 1 & 0 & 0.38 & 0.26 & 0 & 0.7 & 0 & 0 & 0.85 & 0 \\
\hline Jatropha gossypiifolia $L$. & Euphorbiaceae & 0 & 0 & 0 & 0 & 0 & 0 & 0 & & 1 & 0 & 0 & 0 & 0 & 0 & 0 & 0 & 0 & 0 & 0 & 0 & 0 & 0 & 0 & 0 \\
\hline Lannea coromandelica (Houtt.) Merr. & Anacardiaceae & 2 & 10 & 6 & 1 & 4 & 0 & 0 & 0 & 7 & 6 & 6 & 2 & 5 & 0 & 0 & 0 & 0.32 & 0.45 & 0.295 & 1.2 & 1.06 & 0 & 0 & 0 \\
\hline Lepisanthes tetraphylla (Vahl.) Radlk. & Sapindaceae & 71 & 37 & 16 & 2 & 1 & 2 & 0 & 0 & 45 & 36 & 16 & 7 & 1 & 1 & 0 & 0 & 0.13 & 0.12 & 0.18 & 0.46 & 1.01 & 0.8 & 0 & 0 \\
\hline Manilkara hexandra (Roxb.) Dubard & Sapotaceae & 5 & 5 & 19 & 14 & 13 & 5 & 5 & 5 & 2 & 5 & 10 & 12 & 13 & 5 & 5 & 5 & 0.26 & 0.13 & 0.52 & 0.53 & 0.05 & 0.09 & 0.48 & 0.49 \\
\hline Maytenus emarginata (Willd.) Ding Hou & Celastraceae & 1 & 0 & 0 & 0 & 0 & 0 & 0 & 0 & 0 & 0 & 0 & 0 & 0 & 0 & 0 & 0 & 0 & 0 & 0 & 0 & 0 & 0 & 0 & 0 \\
\hline
\end{tabular}




\begin{tabular}{|c|c|c|c|c|c|c|c|c|c|c|c|c|c|c|c|c|c|c|c|c|c|c|c|c|c|}
\hline Memecylon umbellatum Burm.f. & Melastomatace: & 1432 & 149 & 40 & 6 & 5 & 1 & 0 & 0 & 977 & 147 & 33 & 11 & 3 & 0 & 0 & 0 & 0.18 & 0.11 & 0.27 & 0.37 & 0.76 & 0 & 0 & 0 \\
\hline Morinda pubescens J.E. Smith & Rubiaceae & 6 & 4 & 1 & 2 & 1 & 0 & 0 & 0 & 9 & 4 & 1 & 2 & 0 & 0 & 0 & 0 & 0.14 & 0.26 & 0.33 & 0.4 & 0 & 0 & 0 & 0 \\
\hline Phyllanthus polyphyllus Willd. & Euphorbiaceae & 0 & 2 & 0 & 0 & 0 & 0 & 0 & 0 & 1 & 1 & 0 & 0 & 0 & 0 & 0 & 0 & 0 & 1.28 & 0 & 0 & 0 & 0 & 0 & 0 \\
\hline Pleiospermium alatum (Wall. ex Wight.\&Arn.) Sw. & Rutaceae & 4 & 2 & 0 & 0 & 0 & 0 & & 0 & 4 & 1 & 0 & 0 & 0 & 0 & 0 & 0 & 0.61 & 0.55 & 0 & 0 & 0 & 0 & 0 & 0 \\
\hline Pongamia pinnata (L.) Pierre & Papilionaceae & 22 & 18 & 17 & 5 & 6 & 1 & & 2 & 6 & 14 & 10 & 11 & 5 & 2 & 1 & 2 & 0.05 & 0.4 & 0.27 & 0.41 & 0.32 & 0.25 & 0.65 & 1.35 \\
\hline Premna serratifolia $\mathrm{L}$. & Verbenaceae & 0 & 0 & 2 & 0 & 0 & 1 & & 1 & 1 & 0 & 2 & 0 & 0 & & 0 & 1 & 0 & 0 & 0.925 & 0 & 0 & 0 & 0 & 3.65 \\
\hline Prosopis juliflora (Sw.) DC. & Mimosaceae & 9 & 5 & 3 & 1 & 1 & 0 & & 0 & 7 & 5 & 3 & 1 & 2 & 0 & 0 & 0 & 0.27 & 0.58 & 1.42 & 0.05 & 0.15 & 0 & 0 & 0 \\
\hline Pterospermum canescens Roxb. & Sterculiaceae & 88 & 56 & 44 & 28 & 20 & 8 & & 3 & 58 & 52 & 42 & 20 & 16 & & 6 & 6 & 0.137 & 0.14 & 0.18 & 0.31 & 0.18 & 0.22 & 0.38 & 1.07 \\
\hline Sapindus emarginatus Vahl & Sapindaceae & 0 & 1 & 1 & 0 & 0 & 0 & & 0 & 0 & 0 & 1 & 0 & 0 & 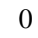 & 0 & 0 & 0 & 0 & 0.7 & 0 & 0 & 0 & 0 & 0 \\
\hline Sapium insigne (Royle) Trimen & Euphorbiaceae & 5 & 2 & 0 & 0 & 2 & 0 & & 0 & 4 & 3 & 0 & 0 & 2 & c & 0 & 0 & 0.11 & 0.52 & 0 & 0 & 0.9 & 0 & 0 & 0 \\
\hline Streblus asper Lour. & Moraceae & 0 & 0 & 0 & 0 & 0 & ( & & 0 & 1 & 0 & 0 & 0 & 0 & & & 0 & 0 & 0 & 0 & 0 & 0 & 0 & 0 & 0 \\
\hline Strychnos nux-vomica $\mathrm{L}$. & Loganiaceae & 155 & 40 & 19 & 11 & 4 & 5 & & 5 & 78 & 54 & 15 & 14 & 8 & 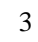 & 2 & 3 & 0.04 & 0.09 & 0.23 & 0.12 & 0.38 & 0.9 & 1.65 & 1.61 \\
\hline Sryrchnos potatorum L.f. & Loganiaceae & 3 & 4 & 1 & 1 & 0 & ( & & 0 & 0 & 4 & 1 & 1 & 0 & & & 0 & 0.6 & 0.54 & 0.45 & 0.4 & 0 & 0 & 0 & 0 \\
\hline Syzygium cumini (L.) Skeels & Myrtaceae & 0 & 3 & 4 & 3 & 4 & 5 & & 8 & 0 & 2 & 2 & 3 & 4 & 2 & 3 & 9 & 0 & 0.1 & 0.35 & 0.77 & 0.65 & 0.21 & 0.64 & 2.68 \\
\hline Tarenna asiatica (L.) Kuntez ex Schumann & Rubiaceae & 36 & 0 & 0 & 0 & 0 & 0 & & 0 & 51 & 3 & 0 & 0 & 0 & & & 0 & 0.18 & 0 & 0 & 0 & 0 & 0 & 0 & 0 \\
\hline Terminalia bellirica (Gaertner) Roxb. & Combretaceae & 0 & 0 & 0 & 0 & 0 & 0 & & & 0 & 0 & 0 & 0 & 0 & & 0 & 1 & 0 & 0 & 0 & 0 & 0 & 0 & 0 & 7.8 \\
\hline Vitex altíssima $\mathrm{L}$. f. & Verbenaceae & 4 & 16 & 13 & 4 & 8 & 4 & & 1 & 6 & 6 & 15 & 8 & 6 & 3 & 0 & 1 & 0.11 & 0.4 & 0.84 & 0.19 & 0.47 & 0.15 & 0 & 1.46 \\
\hline Walsura trifolia (A.Juss.) Harms & Meliaceae & 1 & 0 & 0 & 0 & & ( & & & 0 & 0 & 1 & 0 & 0 & & & 0 & 0 & 0 & 0 & 0 & 0 & 0 & 0 & 0 \\
\hline Wrightia tinctoria (Roxb.) R.Br. & Apocyanaceae & 3 & 1 & 0 & 0 & 0 & 0 & 0 & 0 & 3 & 1 & 0 & 0 & 0 & 0 & 0 & 0 & 0.32 & 0.5 & 0 & 0 & 0 & 0 & 0 & 0 \\
\hline
\end{tabular}

